Review

\title{
Next Generation Sequencing Technology in Lung Cancer Diagnosis
}

\author{
Calin Cainap ${ }^{1,2}$, Ovidiu Balacescu $^{3}\left(\mathbb{D}\right.$, Simona Sorana Cainap ${ }^{4,5, *}$ and Laura-Ancuta Pop ${ }^{6}(\mathbb{D}$ \\ 1 Department of Oncology, "Iuliu Hatieganu” University of Medicine and Pharmacy, \\ 400012 Cluj-Napoca, Romania; Calin.Cainap@umfcluj.ro \\ 2 Ion Chiricuta Institute of Oncology, 400015 Cluj-Napoca, Romania \\ 3 Department of Genetics, Genomics and Experimental Pathology, The Oncology Institute Ion Chiricuta, \\ 400015 Cluj-Napoca, Romania; ovidiubalacescu@iocn.ro \\ 4 Pediatric Clinic no 2, Department of Pediatric Cardiology, Emergency County Hospital for Children, \\ 400177 Cluj-Napoca, Romania \\ 5 Department of Mother and Child, "Iuliu Hatieganu" University of Medicine and Pharmacy, \\ 400013 Cluj-Napoca, Romania \\ 6 Research Center for Functional Genomics, Biomedicine and Translational Medicine, "Iuliu Hatieganu" \\ University of Medicine and Pharmacy, 400337 Cluj-Napoca, Romania; laura.pop@umfcluj.ro \\ * Correspondence: cainap.simona@umfcluj.ro or cainap.simona@gmail.com
}

check for updates

Citation: Cainap, C.; Balacescu, O.; Cainap, S.S.; Pop, L.-A. Next Generation Sequencing Technology in Lung Cancer Diagnosis. Biology 2021, 10, 864. https://doi.org/10.3390/ biology10090864

Academic Editor: William Schierding

Received: 27 July 2021

Accepted: 31 August 2021

Published: 3 September 2021

Publisher's Note: MDPI stays neutral with regard to jurisdictional claims in published maps and institutional affiliations.

Copyright: (c) 2021 by the authors. Licensee MDPI, Basel, Switzerland. This article is an open access article distributed under the terms and conditions of the Creative Commons Attribution (CC BY) license (https:// creativecommons.org/licenses/by/ $4.0 /)$.
Simple Summary: Lung cancer is still one of the most commonly diagnosed and deadliest cancers in the world. Its diagnosis at an early stage is highly necessary and will improve the standard of care of this disease. The aim of this article is to review the importance and applications of next generation sequencing in lung cancer diagnosis. As observed in many studies, next generation sequencing has been proven as a very helpful tool in the early detection of different types of cancers, including lung cancer, and has been used in the clinic, mainly due to its many advantages, such as low cost, speed, efficacy, low quantity usage of biological samples, and diversity.

Abstract: Lung cancer is still one of the most commonly diagnosed cancers, and one of the deadliest. The high death rate is mainly due to the late stage of diagnosis and low response rate to therapy. Previous and ongoing research studies have tried to discover new reliable and useful cbiomarkers for the diagnosis and prognosis of lung cancer. Next generation sequencing has become an essential tool in cancer diagnosis, prognosis, and evaluation of the treatment response. This article aims to review the leading research and clinical applications in lung cancer diagnosis using next generation sequencing. In this scope, we identified the most relevant articles that present the successful use of next generation sequencing in identifying biomarkers for early diagnosis correlated to lung cancer diagnosis and treatment. This technique can be used to evaluate a high number of biomarkers in a short period of time and from small biological samples, which makes NGS the preferred technique to develop clinical tests for personalized medicine using liquid biopsy, the new trend in oncology.

Keywords: lung cancer; next generation sequencing; diagnosis

\section{Lung Cancer}

Lung cancer remains one of the most common cancers diagnosed in 2020, and one of the deadliest cancer types. In Europe, the lung cancer incidence rate is 97.6 (men) and 38.3 (women), with a mortality rate of 81.7 (men) and 29 (women), respectively [1]. In Romania, the incidence is lower in women (28.5) and higher in men (105.3) than the European incidence rate. The same trend is also observed in mortality, 24.8 (women) and 95.6 in men [1]. An increased number of deaths due to lung cancer is mainly due to late-stage diagnosis, mostly because this cancer shows no symptoms in its early stages.

There are several risk factors associated with lung cancer, such as smoking, air pollution, radon exposure, occupational exposure to different chemicals, heredity susceptibility, 
radiation and diet [2]. Considering these risk factors, it has been observed that specific subtypes are correlated to exposure to specific risk factors. These subtypes are small cell lung cancer and non-small cell lung cancer. Small cell lung cancer (SCLC) represents about $15 \%$ of lung cancers and is correlated mainly to smoking. Non-small cell lung cancer (NSCLC) has three main subtypes and accounts for $85 \%$ of lung cancer diagnoses. These subtypes are adenocarcinoma, squamous cell carcinoma and large cell carcinoma [3].

Lung cancer is diagnosed at the late stage mainly because in the early stage it presents no symptoms, and patients approach a doctor only when they experience chest pain, persistent cough, and weight loss. Due to this fact, it is very important to identify reliable methods for screening patients with a high risk for lung cancer. In 2018, the National Comprehensive Cancer Network (NCCN) defined low-dose computer tomography (LDCT) as an early screening method for high-risk lung cancer patients [4]. In a German trial, the LDCT screening helped reduce mortality in women with lung cancer [5]. Two main disadvantages of this technique are that it is recommended for a specific range of patients, mainly people that are smoking or are between 50 and 80 years old, and that there are difficulties in evaluating the correct size and number of lung nodules on CT scans, and sometimes these nodules are benign. To overcome these limitations, new methods for lung screening and diagnosis have been developed [6,7]. It is possible to improve lung cancer screening and diagnosis by using LDCT in combination with different biomarkers, either from serum or blood [8]. On the other hand, due to a lower treatment success rate for late-stage lung cancer, its mortality is relatively high. Moreover, lung cancer patients who smoke present a higher number of somatic mutations, which can give rise to a higher number of cancer-driven mutations [9]. Computer tomography is still the main method used for lung cancer screening and diagnosis [10], and the application of genetic testing is mainly used for treatment selection and guidance. Studies have shown that genetic testing using NGS has helped identify at least one actionable target that could be used for targeted therapy [11-13]. Additionally, it was observed that patients treated with targeted therapies show better survival and response rates [14]. For lung cancer patients, mainly NSCLC, treatment is still based on chemotherapy for initial stages, but in local, advanced or metastatic disease, biomarker testing for different genes (EGFR, ALK, KRAS, ROS1, BRAF, NTRK1/2/3, MET, RET and PD-L1) helps patients benefit from specifically targeted therapies (anti-EGFR, anti-ALK or anti-ROS) and immune checkpoint inhibitor therapy [15].

Therefore, by using and corroborating the data provided by next generation sequencing (NGS) assessment, the early diagnosis and guidance of treatment for lung cancer have become more precise.

\section{Next Generation Sequencing}

Next generation sequencing (NGS) is a comprehensive technology used for sequence (DNA) and gene expression (RNA species) analysis [16-18]. The NGS technique was developed to overcome the Sanger sequencing limitation, but it evolved into being used in all areas of genomic research, starting with DNA, RNA, miRNA, ChIP and methylation sequencing [19-21]. As with any technique, NGS has multiple advantages that have made it an essential tool in all areas of research and in the clinic [22]. However, even after over 15 years of development, this technique has some disadvantages, such as the need for powerful bioinformatics tools and specialized personnel for both experimental and data analysis [20]. Some advantages and disadvantages of NGS are presented in Table 1.

The data provided by NGS have proven valuable and reliable for both research and in the clinic to improve the diagnosis, prognosis, and treatment of several diseases [23-26], and are widely used in the oncology field $[27,28]$. In lung cancer, this technique has been used for early diagnosis biomarker identification, targeted treatment decisions, and identification of causative mutations [29-34]. 
Table 1. Advantages and disadvantages of NGS technology.

\begin{tabular}{cc}
\hline Advantages & Disadvantages \\
\hline Low price & $\begin{array}{c}\text { Need for specialized software and computers } \\
\text { for data analysis }\end{array}$ \\
\hline Short time from library preparation to results & $\begin{array}{c}\text { No standardization or availability of } \\
\text { standardized material for clinical application }\end{array}$ \\
\hline Variety of applications & Still expensive in some developing countries \\
\hline Useful both in research and clinic & \\
\hline $\begin{array}{c}\text { High number of commercially available NGS } \\
\text { platforms and specialized kits }\end{array}$ & \\
\hline
\end{tabular}

\section{NGS in Lung Cancer Diagnosis}

Lung cancer diagnosis is challenging in the early stages because patients do not present any symptoms, or symptoms are shared with other pulmonary diseases. In addition, classic techniques for lung cancer diagnosis have many false-negative results due to different reasons, such as quality and quantity of the samples or sensitivity of the test [35]. Here, NGS can be beneficial due to its high sensitivity and specificity, using low amounts of sample. Additionally, NGS can determine an increased number of alterations simultaneously from the same quantity of sample. Therefore, NGS has been applied with success in the identification of lung cancer-specific mutations in paraffin-embedded tissue samples, with a higher rate than standard PCR testing $[36,37]$. Recently, studies have shown that NGS can effectively be used to identify specific lung cancer mutations in circulating tumor DNA, in a liquid biopsy sample [38-41]. The main applications of NGS in the clinic are related to genomics, transcriptomics and epigenomics. When using whole genome, whole exome or targeted DNA analysis, specific information on point mutations, copy number alterations, small indels or structural variance alterations can be identified. RNA seq analysis can provide information related to gene fusions, alternative splicing, differential expression or RNA editing, while Bisuphite seq or ChIP seq are used for the identification of the methylation profile, histone modification or transcription factor binding alterations.

These important advantages demonstrated by NGS in the evaluation of the alterations related to lung cancer diagnosis have created a new opportunity for the development of commercial kits and assays specific to lung cancer. One such kit is the NextDaySeqLung panel, developed by Beijing ACCB Biotech (Beijing, China), with primers for the amplification of EGFR exon 18, 19, 20, 21, KRAS exon 2, 3, PIK3CA exon 9, 20, and BRAF exon 11, 15. The mutations in the KRAS gene can predict the efficiency of EGFRtyrosine kinase inhibitors [42]. Recently, it was observed that most patients that developed resistance to TKIs have different EGFR mutations [43,44]. Mutations in BRAF can be correlated to response to BRAF/MEK inhibitors in NSCLC patients [45-47], while PIK3CA mutations could render SCLC patients sensible to triciribine treatment [48]. In addition, there is a study that uses alpelisib, a PIK3CA inhibitor, for breast cancer PIK3CA mutated patients, who have shown better survival than that of other treatment [49], which could be implemented in lung cancer as well. The NextDaySeq-Lung panel has been used in several studies and has demonstrated better results than Sanger sequencing or qRT-PCR [50,51]. Other gene panels specific for lung cancer focus on fusion alterations, based on RNA sequencing, and evaluate translocations, chromosomal inversions or interstitial deletions. One such panel is the Ion Ampliseq RNA fusion lung cancer panel offered by ThermoFisher Scientific, Waltham, USA, which targets 70 known fusion transcripts of ALK, RET, ROS1, and NTRK. This panel has shown high sensitivity and good concordance with the typical methods used for fusion testing [52]. For fusion testing, RNA seq has proven to be more sensitive and is used in parallel with DNA seq for mutation evaluation [53,54]. In addition, NGS has successfully been used to identify lung cancer patients that had MET exon14 skipping alterations [55]. Some other NGS lung cancer panels are presented in Table 2. 
Table 2. Some commercially available NGS panels for lung cancer testing.

\begin{tabular}{|c|c|c|c|c|c|c|}
\hline Name & Company & $\begin{array}{c}\text { Type of } \\
\text { Sequencing }\end{array}$ & Gene Targeted & $\begin{array}{l}\text { Target } \\
\text { Approach for } \\
\text { Gene Fusion } \\
\text { Analysis }\end{array}$ & $\begin{array}{c}\text { Input } \\
\text { Nucleic } \\
\text { Acid (ng) }\end{array}$ & Type of Test \\
\hline AccuFusion & $\begin{array}{c}\text { Paragon } \\
\text { Genomics, } \\
\text { Hayward, USA }\end{array}$ & RNA fusion & $\begin{array}{c}\text { ALK, CIT, EML4, } \\
\text { FGFR1, MBIP, MET, } \\
\text { NRG1, NTRK1, } \\
\text { NTRK3, PDGFRA, RET, } \\
\text { ROS1, TACC3. }\end{array}$ & $\begin{array}{l}\text { Amplicon } \\
\text { based }\end{array}$ & 10 & $\begin{array}{c}\text { Diagnosis and } \\
\text { treatment } \\
\text { selection }\end{array}$ \\
\hline OmniFusion & $\begin{array}{c}\text { Paragon } \\
\text { Genomics, } \\
\text { Hayward, USA }\end{array}$ & RNA fusion & $\begin{array}{l}\text { ALK, CIT, MBIP, MET, } \\
\text { NRG1, NTRK1, } \\
\text { NTRK3, PDGFRA, RET, } \\
\text { ROS1, TACC3 }\end{array}$ & $\begin{array}{l}\text { Amplicon } \\
\text { based }\end{array}$ & 25 & $\begin{array}{c}\text { Diagnosis and } \\
\text { treatment } \\
\text { selection }\end{array}$ \\
\hline $\begin{array}{l}\text { Ion AmpliSeq } \\
\text { RNA Fusion } \\
\text { Lung Cancer } \\
\text { Panel }\end{array}$ & $\begin{array}{l}\text { ThermoFisher } \\
\text { Scientific, } \\
\text { Waltham, USA }\end{array}$ & RNA fusion & $\begin{array}{c}\text { ALK, RET, ROS1, and } \\
\text { NTRK }\end{array}$ & $\begin{array}{l}\text { Amplicon } \\
\text { based }\end{array}$ & 10 & $\begin{array}{c}\text { Diagnosis and } \\
\text { treatment } \\
\text { selection }\end{array}$ \\
\hline $\begin{array}{l}\text { QuantideX }{ }^{\circledR} \\
\text { NGS RNA } \\
\text { Lung Cancer } \\
\text { Kit }\end{array}$ & $\begin{array}{c}\text { Asuragen, } \\
\text { Austin, USA }\end{array}$ & $\begin{array}{l}\text { RNA } \\
\text { expression } \\
\text { and fusion }\end{array}$ & $\begin{array}{c}\text { ALK, ROS1, RET, } \\
\text { FGFR3NTRK1, NTRK3, } \\
\text { NRG1, FGFR1, FGFR2, } \\
\text { MBIP, PDGFRA, MET, } \\
\text { ABCB1, BRCA1, } \\
\text { CD274, CDKN2A, } \\
\text { CTLA4, ERCC1, ESR1, } \\
\text { IFNGR, ISG15, MSLN, } \\
\text { PDCD1, PDCD1LG2, } \\
\text { PTEN, RRM1, TDP1, } \\
\text { TERT, TLET3, TOP1, } \\
\text { TUBB3, TYMS }\end{array}$ & $\begin{array}{l}\text { Amplicon } \\
\text { based }\end{array}$ & 10 & $\begin{array}{l}\text { Treatment } \\
\text { selection }\end{array}$ \\
\hline $\begin{array}{l}\text { TruSight RNA } \\
\text { fusion panel }\end{array}$ & $\begin{array}{l}\text { Illumina, San } \\
\text { Diego, USA }\end{array}$ & RNA seq & $\begin{array}{c}507 \text { fusion-associated } \\
\text { genes }\end{array}$ & $\begin{array}{l}\text { Hybrid capture } \\
\text { based }\end{array}$ & $\begin{array}{l}10 \text { total } \\
\text { RNA20-100 } \\
\text { FFPE RNA }\end{array}$ & $\begin{array}{l}\text { Treatment } \\
\text { selection }\end{array}$ \\
\hline $\begin{array}{l}\text { Archer fusion } \\
\text { plex } \\
\text { Comprehensive } \\
\text { Thyroid and } \\
\text { Lung }\end{array}$ & $\begin{array}{l}\text { ArcherDX Inc, } \\
\text { Illumina, San } \\
\text { Diego, USA }\end{array}$ & RNA seq & $\begin{array}{c}\text { gene fusions, SNV, } \\
\text { indels, splicing and } \\
\text { gene expression in } 36 \\
\text { genes }\end{array}$ & AMP based & $10 \mathrm{ng}$ & Diagnosis \\
\hline $\begin{array}{l}\text { Archer fusion } \\
\text { plex Lung kit }\end{array}$ & $\begin{array}{l}\text { ArcherDX Inc, } \\
\text { Illumina, San } \\
\text { Diego, USA }\end{array}$ & $\begin{array}{l}\text { DNA and } \\
\text { RNA seq }\end{array}$ & $\begin{array}{l}\text { EGFR vIII and MET } \\
\text { exon } 14 \text { skipping } \\
\text { events along with } \\
\text { prominent ALK, BRAF, } \\
\text { FGFR, NRG1, NTRK, } \\
\text { RET, and ROS1 fusions } \\
\text { and select point } \\
\text { mutations in } 14 \text { key } \\
\text { gene targets associated } \\
\text { with lung cancer }\end{array}$ & AMP based & $10 \mathrm{ng}$ & Diagnosis \\
\hline $\begin{array}{l}\text { Lung Cancer- } \\
\text { Targeted Gene } \\
\text { Panel, Tumor }\end{array}$ & $\begin{array}{l}\text { MAYO Clinic, } \\
\text { Scottsdale, USA }\end{array}$ & DNA & $\begin{array}{c}\text { EGFR, BRAF, KRAS, } \\
\text { HRAS, NRAS, ALK, } \\
\text { ERBB2, and MET }\end{array}$ & $\begin{array}{l}\text { Amplicon } \\
\text { based }\end{array}$ & NA & $\begin{array}{l}\text { Diagnosis and } \\
\text { management } \\
\text { of lung cancer }\end{array}$ \\
\hline
\end{tabular}


Table 2. Cont.

\begin{tabular}{|c|c|c|c|c|c|c|}
\hline Name & Company & $\begin{array}{c}\text { Type of } \\
\text { Sequencing }\end{array}$ & Gene Targeted & $\begin{array}{l}\text { Target } \\
\text { Approach for } \\
\text { Gene Fusion } \\
\text { Analysis }\end{array}$ & $\begin{array}{c}\text { Input } \\
\text { Nucleic } \\
\text { Acid (ng) }\end{array}$ & Type of Test \\
\hline $\begin{array}{l}\text { Ion AmpliSeq } \\
\text { Colon and } \\
\text { Lung Research } \\
\text { Panel v2 }\end{array}$ & $\begin{array}{l}\text { ThermoFisher } \\
\text { Scientific, } \\
\text { Waltham, USA }\end{array}$ & DNA & $\begin{array}{l}\text { KRAS, EGFR, BRAF, } \\
\text { PIK3CA, AKT1, ERBB2, } \\
\text { PTEN, NRAS, STK11, } \\
\text { MAP2K1, ALK, DDR2, } \\
\text { CTNNB1, MET, TP53, } \\
\text { SMAD4, FBXW7, } \\
\text { FGFR3, NOTCH1, } \\
\text { ERBB4, FGFR1, FGFR2 }\end{array}$ & $\begin{array}{c}\text { Amplicon } \\
\text { based }\end{array}$ & 10 & $\begin{array}{c}\text { Diagnosis and } \\
\text { treatment } \\
\text { selection }\end{array}$ \\
\hline $\begin{array}{l}\text { AmpliSeq for } \\
\text { Illumina Colon } \\
\text { and Lung } \\
\text { Research Panel }\end{array}$ & $\begin{array}{l}\text { Illumina, San } \\
\text { Diego, USA }\end{array}$ & DNA & $\begin{array}{c}\text { KRAS, EGFR, BRAF, } \\
\text { PIK3CA, AKT1, ERBB2, } \\
\text { PTEN, NRAS, STK11, } \\
\text { MAP2K1, ALK, DDR2, } \\
\text { CTNNB1, MET, TP53, } \\
\text { SMAD4, FBXW7, } \\
\text { FGFR3, NOTCH1, } \\
\text { ERBB4, FGFR1, and } \\
\text { FGFR2 }\end{array}$ & $\begin{array}{c}\text { Amplicon } \\
\text { based }\end{array}$ & 10 & $\begin{array}{c}\text { Diagnosis and } \\
\text { treatment } \\
\text { selection }\end{array}$ \\
\hline
\end{tabular}

It is well known that cancer is considered a genetic disorder in which somatic mutations accumulate and give cancer cells the ability to over proliferate and avoid apoptosis [56,57]. Lung cancer is one of the cancers that exhibit a high degree of mutation burden and a high number of driven mutations [9]. Consequently, NGS is extremely useful, due to its many advantages, and the development of different NGS panels is implemented in the clinical setting. In lung cancer diagnosis, NGS is employed mainly in evaluating the gene alteration in key genes involved in the development of lung cancer. These genes are EGFR, BRAF, KRAS, HER2, ROS, ALK, PIK3CA, NTRK, RET and MET [58]. One example is using CGH NGS-based assay for assessing 51 FFPE samples of adenocarcinoma to evaluate its efficiency compared to standard mutation testing. The authors observed that $58 \%$ of wild-type patients presented alterations in one of these genes when using the NGS approach, making them suitable for targeted therapy [35]. In other studies, NGS was implemented for NSCLC diagnosis due to the small quantity of tissue samples, which is not suitable for traditional testing methods. Hagemman et al. successfully sequenced 209 samples of NSCLC using a 28 gene NGS panel and identified actionable mutations in $46 \%$ of the tested samples [36]. In the same line, Moskalev et al. used the 454 NGS system to evaluate EGFR and KRAS mutation in NSCLC samples with a low number of tumor cells. They were able to identify mutations with an allele frequency of $0.2-1.5 \%$. When reevaluating 16 cases with low tumor cells that were wild type by Sanger, seven of them presented mutations in the EGFR gene at a frequency of $0.9-10 \%$ [37]. Another study compared an NGS panel, Sanger sequencing, and qRT-PCR in evaluating mutation in 138 NSCLC FFPE samples. The authors observed that NGS and qRT-PCR have a higher sensitivity than Sanger sequencing. NGS is better than qRT-PCR because it also provides information about the mutation sequence and allele frequency, and identifies mutations that are not in the hotspot area [50]. Liang et al. used a DNA methylation profile to develop a blood-based test for the early diagnosis of lung cancer. Their method presented a sensitivity of $75 \%$ for stage $1 \mathrm{~A}$ and 85.7 for stage 1B lung cancer [59]. NGS has proven to be more sensitive and specific than FISH or IHC when analyzing fusion alterations in lung cancer, which are the main methods used for fusion detection. Lin et al. observed a positive rate of $92.7 \%$ for ALK rearrangement when using NGS, $82.4 \%$ for FISH and $94.5 \%$ for IHC, and a concordance of $87.3 \%$ of NGS results with IHC results. They also concluded that IHC fusion testing is better for screening, while NGS fusion testing 
is more accurate for predicting the clinical benefits of crizotinib treatment [60]. Another benefit of NGS is the fact that it also provides information on the exact fusion alteration, which is very important in evaluating the treatment and outcome of patients [61]. To overcome the problem of harvesting tissue samples from early-stage lung cancer sample patients, new challenges related to identifying novel non-invasive biomarkers are under investigation. One such example is the use of miRNA for the diagnosis of lung cancer. miRNA sequencing was used to identify specific miRNAs for adenocarcinoma and SCLC. Jin et al. were able to identify miR-181-5p, miR-30a-3p, miR-30e-3p and miR-361-5p as being specific for adenocarcinoma, and miR-10b-5p, miR-15b-5p and miR-320b for SCLC (small cell lung cancer) [62]. In addition, taking advantage of the many benefits of NGS, oncology researchers have developed liquid biopsy testing for lung cancer diagnosis [63]. Leighl et al. observed a very high concordance for NGS results from cfDNA and tissue DNA in untreated metastatic NSCLC [64]. The same was observed by Mack et al. when analyzing 8388 cases of NSCLC [65]. NGS testing was successfully recommended in lung cancer diagnosis by different expert panels [66] and oncology organizations [67]. Gray et al. performed a thorough survey of the relevant literature regarding liquid biopsy and observed that the advantages of NGS have helped to develop different assays using liquid biopsy samples for the early diagnosis, treatment selection, minimal disease detection, monitoring treatment efficacy and evaluation of tumor burden in lung cancer [63]. SueokaAragane et al. observed that the analysis of ctDNA by NGS could be a promising tool for the evaluation of the efficacy of osimertinib in NSCLC with EGFR T790M mutation [68]. Table 3 presents studies correlated to the performance of NGS technology in the diagnosis and screening of lung cancer $[69,70]$.

Table 3. Studies describing the implication of NGS in lung cancer diagnosis.

\begin{tabular}{|c|c|c|c|c|c|c|}
\hline Samples & $\begin{array}{l}\text { Correlation with } \\
\text { Other Techniques }\end{array}$ & NGS Method & $\begin{array}{l}\text { Type of Lung } \\
\text { Cancer }\end{array}$ & Specificity (\%) & Sensitivity (\%) & Ref. \\
\hline $\begin{array}{c}31 \text { tissues lung } \\
\text { samples negative for } \\
\text { mutations by FISH } \\
\text { or PCR }\end{array}$ & $\begin{array}{l}8 / 31 \text { presented } \\
\text { actionable } \\
\text { mutations }\end{array}$ & $\begin{array}{c}\text { Broad, hybrid } \\
\text { capture-based } \\
\text { NGS }\end{array}$ & Adenocarcinoma & NA & NA & [70] \\
\hline $\begin{array}{l}40 \text { FFPE tissue with } \\
\text { known fusion (test), } \\
59 \text { FFPE } \\
\text { fusion-negative } \\
\text { (validation) }\end{array}$ & $\begin{array}{c}\text { Good concordance } \\
\text { with FISH, PCR or } \\
\text { Sanger }\end{array}$ & $\begin{array}{l}\text { RNA seq gene } \\
\text { fusion }\end{array}$ & NA & 93-100 & $86-100$ & [71] \\
\hline $\begin{array}{l}28 \text { fusion positive } \\
\text { FISH sample }\end{array}$ & $\begin{array}{c}16 \text { were positive in } \\
\text { NGS }\end{array}$ & $\begin{array}{l}\text { RNA fusion } \\
\text { and DNA seq }\end{array}$ & NSCLC & NA & NA & [72] \\
\hline $32 \mathrm{FFPE}$ & $\begin{array}{l}\text { Good concordance } \\
\text { with FISH and } \\
\text { qRT-PCR }\end{array}$ & RNA seq & NSCLC & 100 & 100 & [73] \\
\hline $\begin{array}{c}50 \text { FFPE (35 test } \\
\text { positive for different } \\
\text { fusion alterations, } 15 \\
\text { negative) } \\
\text { 109 FFPE } \\
\text { (validation) }\end{array}$ & $\begin{array}{l}\text { Good concordance } \\
\text { with FISH }\end{array}$ & $\begin{array}{l}\text { RNA fusion } \\
\text { and DNA seq }\end{array}$ & NSCLC & 100 & 100 & [74] \\
\hline $\begin{array}{l}31 \text { FFPE positive for } \\
\text { rearrangement by } \\
\text { FISH }\end{array}$ & $\begin{array}{l}26 \text { were positive in } \\
\text { NGS and were } \\
\text { confirmed by IHC }\end{array}$ & $\begin{array}{l}\text { RNA fusion } \\
\text { and DNA seq }\end{array}$ & NSCLC & NA & NA & [75] \\
\hline $\begin{array}{l}51 \text { tested with FISH, } \\
\text { IHC and NGS }\end{array}$ & $\begin{array}{l}8 \text { samples positive } \\
\text { by NGS and IHC, } \\
\text { only } 4 \text { by FISH }\end{array}$ & DNA seq & Adenocarcinoma & 100 & 100 & [76] \\
\hline
\end{tabular}


Table 3. Cont.

\begin{tabular}{|c|c|c|c|c|c|c|}
\hline Samples & $\begin{array}{l}\text { Correlation with } \\
\text { Other Techniques }\end{array}$ & NGS Method & $\begin{array}{l}\text { Type of Lung } \\
\text { Cancer }\end{array}$ & Specificity (\%) & Sensitivity (\%) & Ref. \\
\hline $\begin{array}{l}19 \text { FFPE tested with } \\
\text { IHC and NGS }\end{array}$ & $\begin{array}{c}\text { Good concordance } \\
\text { between NGS and } \\
\text { IHC }\end{array}$ & DNA seq & Adenocarcinoma & NA & NA & [77] \\
\hline $\begin{array}{c}63 \text { tissue, urine and } \\
\text { plasma }\end{array}$ & $\begin{array}{l}\text { NGS testing of urine } \\
\text { and plasma } \\
\text { presented more } \\
\text { EGFR mutated } \\
\text { positive samples } \\
\text { that tissue samples } \\
\text { tested by RT-PCR }\end{array}$ & DNA seq & NSCLC & $\begin{array}{l}94 \text { for urine } \\
96-100 \text { for } \\
\text { plasma }\end{array}$ & $\begin{array}{c}\text { 80-93 for urine } \\
\text { 87-100 for } \\
\text { plasma }\end{array}$ & [78] \\
\hline $\begin{array}{c}3 \text { cases with } \\
\text { multiple resected } \\
\text { tumors }\end{array}$ & $\begin{array}{l}\text { NGS revealed } \\
\text { different molecular } \\
\text { characteristics that } \\
\text { the normal } \\
\text { pathological } \\
\text { diagnosis }\end{array}$ & DNA seq & Adenocarcinoma & NA & NA & [79] \\
\hline
\end{tabular}

The research area using NGS for lung cancer diagnosis has been extensively developed and has made this technique valuable for different clinical trials on lung cancer. Data from cl inicaltrial.gov include 98 trials on lung cancer that use NGS (https: / / clinicaltrials.gov / ct2/r esults?cond $=$ Lung + Cancer\&term $=$ next + generation + sequencing\&cntry\&state $=\& c i t y=\& d i s$ $t=$, accessed on 25 July 2021). Some of these trials are already complete; others are recruiting or enrolling. There are clinical trials that evaluate the possibility of NGS to identify mutations in very small samples (NGS NCT02420405), or improve the personalized treatment (NCT02281214). Table 4 presents data on the clinical trials using NGS for lung cancer diagnosis.

Table 4. Clinical trials on lung cancer diagnosis using NGS technology.

\begin{tabular}{|c|c|c|c|c|c|}
\hline Trial No & Condition & Scope of the Trial & Sample Type & $\begin{array}{l}\text { Number of } \\
\text { Patients }\end{array}$ & Results \\
\hline NCT03558165 & $\begin{array}{l}\text { Lung adenocarcinoma } \\
\text { stage IV }\end{array}$ & $\begin{array}{l}\text { Diagnostic test: oncomine } \\
\text { comprehensive assay }\end{array}$ & FFPE tissue & 100 & NA \\
\hline NCT02420405 & $\begin{array}{c}\text { Non-squamous NSCLC } \\
\text { stage IIIA-IV }\end{array}$ & $\begin{array}{l}\text { Routine gene testing by } \\
\text { NGS for diagnosis }\end{array}$ & Tissue & 78 & NA \\
\hline NCT02297087 & Incurable SCLC & $\begin{array}{l}\text { Standard of care based on } \\
\text { target(s) identified via } \\
\text { GWAS for diagnosis and } \\
\text { treatment }\end{array}$ & $\begin{array}{l}\text { Blood and } \\
\text { tissue }\end{array}$ & 12 & NA \\
\hline NCT02281214 & $\begin{array}{c}\text { Bronchial } \\
\text { adenocarcinoma with } \\
\text { metastases, epidermoid } \\
\text { cancer of the lungs }\end{array}$ & $\begin{array}{l}\text { NGS testing for treatment } \\
\text { selection and prognostic }\end{array}$ & $\begin{array}{l}\text { Blood and } \\
\text { tissue }\end{array}$ & 165 & NA \\
\hline NCT03257735 & $\begin{array}{l}\text { NSCLC with brain } \\
\text { metastasis }\end{array}$ & $\begin{array}{c}\text { Consistency of gene } \\
\text { mutation status between } \\
\text { different types of samples } \\
\text { using NGS }\end{array}$ & $\begin{array}{l}\text { Cerebrospinal } \\
\text { fluid, blood } \\
\text { and tissue }\end{array}$ & 50 & NA \\
\hline NCT04849481 & NSCLC & $\begin{array}{l}\text { Large-scale NGS analysis } \\
\text { for novel treatment } \\
\text { strategies and deciphering } \\
\text { the mechanisms of drug } \\
\text { resistance }\end{array}$ & Tissue & 500 & NA \\
\hline
\end{tabular}


Table 4. Cont.

\begin{tabular}{|c|c|c|c|c|c|}
\hline Trial No & Condition & Scope of the Trial & Sample Type & $\begin{array}{l}\text { Number of } \\
\text { Patients }\end{array}$ & Results \\
\hline NCT03244904 & SCLC & $\begin{array}{c}\text { NGS analysis for } \\
\text { biomarkers for SCLC }\end{array}$ & $\begin{array}{l}\text { Blood and } \\
\text { tissue }\end{array}$ & 80 & NA \\
\hline NCT02416726 & Non-squamous NSCLC & $\begin{array}{c}\text { NGS for gene profile } \\
\text { comparison between } \\
\text { different types of samples }\end{array}$ & $\begin{array}{l}\text { Blood and } \\
\text { tissue }\end{array}$ & 35 & NA \\
\hline NCT04260295 & $\begin{array}{l}\text { Lung cancer and } \\
\text { non-lung cancer patients }\end{array}$ & $\begin{array}{l}\text { NGS for identification of } \\
\text { microorganisms in lungs }\end{array}$ & Tissue & 300 & NA \\
\hline NCT02705404 & Multifocal lung cancer & $\begin{array}{l}\text { NGS for differentiation of } \\
\text { primary tumors from } \\
\text { metastatic tumors }\end{array}$ & $\begin{array}{l}\text { Blood, cytology } \\
\text { and tissue }\end{array}$ & 100 & NA \\
\hline NCT02705404 & NSCLC & $\begin{array}{l}\text { Targeted NGS for } \\
\text { mutation profile } \\
\text { concordance in different } \\
\text { types of samples }\end{array}$ & $\begin{array}{l}\text { Blood, fresh } \\
\text { frozen and } \\
\text { FFPE tissue }\end{array}$ & 45 & NA \\
\hline NCT03833934 & NSCLC & $\begin{array}{c}\text { NGS testing for evaluation } \\
\text { of ALK resistant } \\
\text { mutations }\end{array}$ & Plasma & 300 & NA \\
\hline NCT03220230 & NSCLC & $\begin{array}{l}\text { Concordance between } \\
\text { NGS and IHC ALK status }\end{array}$ & $\begin{array}{l}\text { Tissue and } \\
\text { blood }\end{array}$ & 4240 & $\begin{array}{c}\text { Accuracy } 95.9 \% \text { for } \\
1450 \text { participants, } \\
\text { sensitivity } 54.2 \% \text { for } \\
83 \text { participants, } \\
\text { specificity } 98.4 \% \text { for } \\
1367 \text { participants }\end{array}$ \\
\hline NCT03658460 & NSCLC & $\begin{array}{l}\text { Gene testing using NGS } \\
\text { with focus on immuno- } \\
\text { oncology markers }\end{array}$ & Tissue & 100 & NA \\
\hline NCT02273336 & Lung cancer & $\begin{array}{l}\text { NGS testing for treatment } \\
\text { selection }\end{array}$ & $\begin{array}{l}\text { Tissue, blood } \\
\text { and cytology }\end{array}$ & 40 & NA \\
\hline NCT02941003 & Lung adenocarcinoma & $\begin{array}{c}\text { NGS for early stage } \\
\text { diagnosis }\end{array}$ & Tissue & 540 & NA \\
\hline NCT04238130 & NSCLC & $\begin{array}{c}\text { NGS assessment of } \\
\text { mutation profile in } \\
\text { personalized analysis of } \\
\text { cancer }\end{array}$ & Plasma & 200 & NA \\
\hline NCT02169349 & Stage IIIb and IV NSCLC & $\begin{array}{l}\text { NGS evaluation cfDNA } \\
\text { for diagnosis, treatment } \\
\text { and disease progression }\end{array}$ & Plasma & 100 & NA \\
\hline NCT02299622 & $\begin{array}{l}\text { NSCLC, head and neck } \\
\text { cancer, esophageal } \\
\text { cancer }\end{array}$ & $\begin{array}{l}\text { NGS testing for evaluation } \\
\text { of mutation profile }\end{array}$ & Tissue & 200 & NA \\
\hline NCT02778854 & NSCLC & $\begin{array}{l}\text { Genetic detection of driver } \\
\text { mutation using ddPCR } \\
\text { and NGS for evaluation of } \\
\text { the efficacy of liquid } \\
\text { biopsy in diagnosis and } \\
\text { prognosis }\end{array}$ & $\begin{array}{l}\text { Tissue, plasma } \\
\text { and other } \\
\text { biological } \\
\text { liquids }\end{array}$ & 200 & NA \\
\hline NCT03486262 & $\begin{array}{c}\text { Lung carcinoma patients } \\
\text { with/withoutidiopathic } \\
\text { pulmonary fibrosis } \\
\text { (IPH) }\end{array}$ & $\begin{array}{l}\text { NGS testing for genetic } \\
\text { alterations identification } \\
\text { in lung cancer patients } \\
\text { with IPH and without IPH }\end{array}$ & Tissue & 100 & NA \\
\hline
\end{tabular}


Table 4. Cont.

\begin{tabular}{|c|c|c|c|c|c|}
\hline Trial No & Condition & Scope of the Trial & Sample Type & $\begin{array}{l}\text { Number of } \\
\text { Patients }\end{array}$ & Results \\
\hline NCT02113852 & NSCLC & $\begin{array}{c}\text { NGS study for } \\
\text { identification and } \\
\text { characterization of genetic } \\
\text { and transcriptomic } \\
\text { alteration }\end{array}$ & $\begin{array}{l}\text { Tissue and } \\
\text { blood }\end{array}$ & 250 & NA \\
\hline NCT03771404 & $\begin{array}{l}\text { Operable (stages I-IIIA) } \\
\text { NSCLC Patients }\end{array}$ & $\begin{array}{l}\text { NGS evaluation of the } \\
\text { genetic landscape of each } \\
\text { patient in order to } \\
\text { determine heterogeneity } \\
\text { in early stage NSCLC }\end{array}$ & $\begin{array}{l}\text { Blood and } \\
\text { tissue }\end{array}$ & 50 & NA \\
\hline NCT04698681 & $\begin{array}{l}\text { Stage IV non-squamous } \\
\text { NSCLC }\end{array}$ & $\begin{array}{c}\text { NGS evaluation for tumor } \\
\text { mutations identification in } \\
\text { the KEAP1 or } \\
\text { NRF2/NFE2L2 genes in } \\
\text { order to determine } \\
\text { potential eligibility for a } \\
\text { biomarker selected clinical } \\
\text { trial }\end{array}$ & Blood & 200 & NA \\
\hline NCT04266483 & NSCLC & $\begin{array}{l}\text { Molecular typing of lung } \\
\text { cancer in China }\end{array}$ & $\begin{array}{l}\text { Blood and } \\
\text { tissue }\end{array}$ & 2500 & NA \\
\hline NCT04624373 & Stage IV lung cancer & $\begin{array}{l}\text { Molecular analysis to } \\
\text { investigate the sensitivity } \\
\text { of cytology supernatant } \\
\text { DNA for genotyping }\end{array}$ & $\begin{array}{l}\text { Supernatant, } \\
\text { blood and } \\
\text { tissue }\end{array}$ & 50 & NA \\
\hline NCT02718651 & NSCLC & $\begin{array}{l}\text { New diagnostic test to } \\
\text { detect ALK } \\
\text { rearrangements using } \\
\text { NGS }\end{array}$ & plasma & 70 & NA \\
\hline NCT03576937 & Non-squamous NSCLC & $\begin{array}{l}\text { Comparison of } \\
\text { blood-based mutational } \\
\text { profile with tissue } \\
\text { mutational profile for } \\
\text { diagnosis }\end{array}$ & $\begin{array}{l}\text { Blood and } \\
\text { tissue }\end{array}$ & 207 & NA \\
\hline NCT03248089 & Non-squamous NSCLC & $\begin{array}{l}\text { Investigation of the } \\
\text { efficacy of cfDNA } \\
\text { genotyping for diagnosis }\end{array}$ & $\begin{array}{l}\text { Blood and } \\
\text { tissue }\end{array}$ & 186 & NA \\
\hline NCT03317080 & $\begin{array}{l}\text { I-IV lung cancer eligible } \\
\text { for surgery. }\end{array}$ & $\begin{array}{l}\text { Use of liquid biopsy for } \\
\text { lung cancer detection }\end{array}$ & Blood & 1500 & NA \\
\hline NCT04025515 & $\begin{array}{l}\text { Asian patients with } \\
\text { NSCLC }\end{array}$ & $\begin{array}{l}\text { Comprehensive molecular } \\
\text { profiling of "actionable" } \\
\text { alterations in lung cancer } \\
\text { specimens in order to } \\
\text { determine the prevalence } \\
\text { of each genetic subtype in } \\
\text { the local population. }\end{array}$ & Tissue & 500 & NA \\
\hline NCT03706625 & $\begin{array}{l}\text { Immune-suppressed } \\
\text { patients suffering from } \\
\text { HIV-related NSCLC }\end{array}$ & $\begin{array}{l}\text { Identify novel biomarkers } \\
\text { such as tumor mutational } \\
\text { profiling and } \\
\text { immunomutanome in } \\
\text { immunosuppressed } \\
\text { patients }\end{array}$ & Tissue & 170 & NA \\
\hline
\end{tabular}


Table 4. Cont.

\begin{tabular}{|c|c|c|c|c|c|}
\hline Trial No & Condition & Scope of the Trial & Sample Type & $\begin{array}{l}\text { Number of } \\
\text { Patients }\end{array}$ & Results \\
\hline NCT03651986 & $\begin{array}{l}\text { Patients with benign } \\
\text { and malignant } \\
\text { pulmonary nodules }\end{array}$ & $\begin{array}{l}\text { Development of a } \\
\text { blood-based assay for } \\
\text { early differentiation of } \\
\text { benign and malignant } \\
\text { pulmonary nodules }\end{array}$ & Blood & 10,560 & NA \\
\hline NCT02906943 & $\begin{array}{l}\text { Several cancer including } \\
\text { lung cancer }\end{array}$ & $\begin{array}{l}\text { NGS evaluation of } \\
\text { different types of cancer } \\
\text { for biomarker } \\
\text { identification }\end{array}$ & FFPE tissue & 10,000 & NA \\
\hline NCT03609918 & NSCLC & $\begin{array}{l}\text { To build NSCLC gene } \\
\text { mutation profile in China } \\
\text { and find related } \\
\text { correlation between gene } \\
\text { mutation panel and } \\
\text { clinical outcome }\end{array}$ & $\begin{array}{l}\text { Fresh frozen } \\
\text { tissues and } \\
\text { FFPE tissues }\end{array}$ & 513 & NA \\
\hline NCT03029065 & $\begin{array}{l}\text { Lung cancer patients } \\
\text { with brain metastases }\end{array}$ & $\begin{array}{l}\text { To determine whether } \\
\text { cfDNA can be used for } \\
\text { concomitant diagnosis to } \\
\text { improve the treatment } \\
\text { efficacy and prognosis of } \\
\text { patients with brain } \\
\text { (meningeal) metastasis }\end{array}$ & $\begin{array}{l}\text { Tissue, plasma } \\
\text { and } \\
\text { cerebrospinal } \\
\text { fluids }\end{array}$ & 50 & NA \\
\hline NCT03971175 & $\begin{array}{l}\text { Lung cancer and relapse } \\
\text { NSCLC }\end{array}$ & $\begin{array}{c}\text { To evaluate accuracy of } \\
\text { molecular genetic } \\
\text { characterisation of NSCLC }\end{array}$ & $\begin{array}{c}\text { Tissue, } \\
\text { cytology and } \\
\text { liquid biopsy }\end{array}$ & 540 & NA \\
\hline NCT04692935 & $\begin{array}{l}\text { Lung adenocarcinoma } \\
\text { from asian and } \\
\text { Caucasian patients }\end{array}$ & $\begin{array}{l}\text { Evaluation of the } \\
\text { mutational profile by race }\end{array}$ & Tissue & 450 & NA \\
\hline
\end{tabular}

In addition, recent studies have shown that by implementing NGS-based testing, clinics can reduce the cost required for evaluating biomarkers specifically for targeted treatments or agnostic therapy implementation. NGS-based testing can reduce total testing cost by EUR 30-1249 depending on how comprehensive the analysis is, when compared to RT-PCR technology [80].

\section{Conclusions}

NGS has successfully been used both in research and in the clinic, and has become one of the main tools in lung cancer diagnosis, showing better results that standard techniques used for lung cancer diagnosis, and being able to identify lung cancer-specific alteration in a variety of biological samples such as blood, plasma, fresh frozen or FFPE tissue, urine or other bodily fluids, even where the nucleic acid content is limited and where classic methods fail. In addition, the cost of NGS is lower than that of standard testing methods, which makes this technique appealing for the implementation of different agnostic therapies, targeted therapies and immune checkpoint inhibitor therapies. Its success was demonstrated in different clinical studies that were developed to obtain better methods for lung cancer diagnosis. The NGS technique has become the primary tool for investigating different types of samples and different subtypes of lung cancer, being implemented in mutation evaluation and fusion alteration identification, due to its great advantage over FISH and IHC, which are techniques that can have inconsistent results due to the expertise of the pathologist, and cannot be used on other types of samples, except tissue. As with any technique, NGS still has its limitations, mostly related to the amount of data obtained, and the need for a big data storage capacity and a good bioinformatics team. 
Nevertheless, the advantages of NGS make it ideal to be used for evaluating a high number of biomarkers in a short period of time, from small biological samples, and at a low price. Therefore, NGS should be the preferred technique to develop clinical tests for personalized medicine using liquid biopsy, the new trend in oncology.

Author Contributions: Conceptualization, C.C. and L.A.P.; data curation, O.B. and S.S.C.; writingoriginal draft preparation, C.C., O.B., S.S.C. and L.A.P.; writing-review and editing, O.B. and L.P.; visualization, S.S.C. and L.P.; supervision, L.P. All authors have read and agreed to the published version of the manuscript.

Funding: This research was funded by the FEDR through the Competitiveness Operational Programme 2014-2020, POC-P_40_318, contract no. 10/01.09.2016: Grant partnership for the transfer of knowledge in biogenomics applications in oncology and related fields, BIOGENONCO.

Institutional Review Board Statement: Not applicable.

Informed Consent Statement: Not applicable.

Data Availability Statement: Not applicable.

Acknowledgments: The authors would also like to thank Sanogenetic (Voluntari, Romania) for their help with this manuscript.

Conflicts of Interest: The authors declare no conflict of interest.

\begin{abstract}
Abbreviations
cfDNA: circulating free DNA; CGH: comparative genomic hybridization; ChIP Seq: chromatin immune-precipitation and DNA sequencing; CT: computer tomography; ddPCR: digital droplet polymerase chain reaction; DNA: deoxiribonucleic acid; FFPE: formalin fixed paraffin embedded; FISH: fluorescence in situ hybridization; GWAS: genome wide association studies; IHC: imunohisto chemistry; IPH: idiopathic pulmonary fibrosis; LC: lung cancer; LDCT: low dose computer tomography; miRNA: micro RNA; NCCN: National Comprehensive Cancer Network; NGS: next generation sequencing; NSCLC: non-small cell lung cancer; PCR: polymerase chain reaction; qRT-PCR: quantitative real time polymerase chain reaction; RNA: ribonucleic acid; SCLC: small cell lung cancer.
\end{abstract}

\title{
References
}

1. System, E.-E.C.I. Lung cancer incidance and mortality 2020. 2021. Available online: https:/ / ecis.jrc.ec.europa.eu (accessed on 26 July 2021).

2. Mao, Y.; Yang, D.; He, J.; Krasna, M.J. Epidemiology of Lung Cancer. Surg. Oncol. Clin. N. Am. 2016, 25, 439-445. [CrossRef] [PubMed]

3. Travis, W.D.; Brambilla, E.; Burke, A.P.; Marx, A.; Nicholson, A.G. Introduction to The 2015 World Health Organization Classification of Tumors of the Lung, Pleura, Thymus, and Heart. J. Thorac. Oncol. Off. Publ. Int. Assoc. Study Lung Cancer 2015, 10, 1240-1242. [CrossRef] [PubMed]

4. Wood, D.E.; Kazerooni, E.A.; Baum, S.L.; Eapen, G.A.; Ettinger, D.S.; Hou, L.; Jackman, D.M.; Klippenstein, D.; Kumar, R.; Lackner, R.P.; et al. Lung Cancer Screening, Version 3.2018, NCCN Clinical Practice Guidelines in Oncology. J. Natl. Compr. Cancer Netw. JNCCN 2018, 16, 412-441. [CrossRef]

5. Becker, N.; Motsch, E.; Trotter, A.; Heussel, C.P.; Dienemann, H.; Schnabel, P.A.; Kauczor, H.U.; Maldonado, S.G.; Miller, A.B.; Kaaks, R.; et al. Lung cancer mortality reduction by LDCT screening-Results from the randomized German LUSI trial. Int. J. Cancer 2020, 146, 1503-1513. [CrossRef] [PubMed]

6. Han, D.; Heuvelmans, M.A.; Oudkerk, M. Volume versus diameter assessment of small pulmonary nodules in CT lung cancer screening. Transl. Lung Cancer Res. 2017, 6, 52-61. [CrossRef] [PubMed]

7. Cainap, C.; Pop, L.A.; Balacescu, O.; Cainap, S.S. Early diagnosis and screening in lung cancer. Am. J. Cancer Res. 2020, 10, 1993-2009.

8. Chu, G.C.W.; Lazare, K.; Sullivan, F. Serum and blood based biomarkers for lung cancer screening: A systematic review. BMC Cancer 2018, 18, 181. [CrossRef] [PubMed]

9. Alexandrov, L.B.; Nik-Zainal, S.; Wedge, D.C.; Aparicio, S.A.; Behjati, S.; Biankin, A.V.; Bignell, G.R.; Bolli, N.; Borg, A.; Børresen-Dale, A.L.; et al. Signatures of mutational processes in human cancer. Nature 2013, 500, 415-421. [CrossRef]

10. Oudkerk, M.; Devaraj, A.; Vliegenthart, R.; Henzler, T.; Prosch, H.; Heussel, C.P.; Bastarrika, G.; Sverzellati, N.; Mascalchi, M.; Delorme, S.; et al. European position statement on lung cancer screening. Lancet. Oncol. 2017, 18, e754-e766. [CrossRef] 
11. Johnson, D.B.; Dahlman, K.H.; Knol, J.; Gilbert, J.; Puzanov, I.; Means-Powell, J.; Balko, J.M.; Lovly, C.M.; Murphy, B.A.; Goff, L.W.; et al. Enabling a genetically informed approach to cancer medicine: A retrospective evaluation of the impact of comprehensive tumor profiling using a targeted next-generation sequencing panel. Oncologist 2014, 19, 616-622. [CrossRef] [PubMed]

12. Tan, O.; Shrestha, R.; Cunich, M.; Schofield, D.J. Application of next-generation sequencing to improve cancer management: A review of the clinical effectiveness and cost-effectiveness. Clin. Genet. 2018, 93, 533-544. [CrossRef]

13. Meric-Bernstam, F.; Brusco, L.; Shaw, K.; Horombe, C.; Kopetz, S.; Davies, M.A.; Routbort, M.; Piha-Paul, S.A.; Janku, F.; Ueno, N.; et al. Feasibility of Large-Scale Genomic Testing to Facilitate Enrollment Onto Genomically Matched Clinical Trials. J. Clin. Oncol. Off. J. Am. Soc. Clin. Oncol. 2015, 33, 2753-2762. [CrossRef]

14. Schwaederle, M.; Zhao, M.; Lee, J.J.; Lazar, V.; Leyland-Jones, B.; Schilsky, R.L.; Mendelsohn, J.; Kurzrock, R. Association of Biomarker-Based Treatment Strategies With Response Rates and Progression-Free Survival in Refractory Malignant Neoplasms: A Meta-analysis. JAMA Oncol. 2016, 2, 1452-1459. [CrossRef] [PubMed]

15. Consortium, N. NCCN Guidlines-Non Small Cell Lung Cancer; NCCN: Plymouth Meeting, PA, USA, 2021.

16. Cirulli, E.T.; Goldstein, D.B. Uncovering the roles of rare variants in common disease through whole-genome sequencing. Nat. Rev. Genet. 2010, 11, 415-425. [CrossRef]

17. Sultan, M.; Schulz, M.H.; Richard, H.; Magen, A.; Klingenhoff, A.; Scherf, M.; Seifert, M.; Borodina, T.; Soldatov, A.; Parkhomchuk, D.; et al. A global view of gene activity and alternative splicing by deep sequencing of the human transcriptome. Science 2008, 321, 956-960. [CrossRef] [PubMed]

18. Ju, Y.S.; Kim, J.I.; Kim, S.; Hong, D.; Park, H.; Shin, J.Y.; Lee, S.; Lee, W.C.; Kim, S.; Yu, S.B.; et al. Extensive genomic and transcriptional diversity identified through massively parallel DNA and RNA sequencing of eighteen Korean individuals. Nat. Genet. 2011, 43, 745-752. [CrossRef] [PubMed]

19. Behjati, S.; Tarpey, P.S. What is next generation sequencing? Arch. Dis. Child. Educ. Pract. Ed. 2013, 98, 236-238. [CrossRef]

20. Levy, S.E.; Myers, R.M. Advancements in Next-Generation Sequencing. Annu. Rev. Genom. Hum. Genet. 2016, 17, 95-115. [CrossRef]

21. Slatko, B.E.; Gardner, A.F.; Ausubel, F.M. Overview of Next-Generation Sequencing Technologies. Curr. Protoc. Mol. Biol. 2018, 122, e59. [CrossRef] [PubMed]

22. Pereira, M.A.; Malta, F.S.V.; Freire, M.C.M.; Couto, P.G.P. Application of Next-Generation Sequencing in the Era of Precision Medicine. In Applications of RNA-Seq and Omics Strategies_From Microorganisms to Human Health; Marchi, F., Cirillo, P., Mateo, E.C., Eds.; IntechOpen: London, UK, 2017. [CrossRef]

23. Spaulding, T.P.; Stockton, S.S.; Savona, M.R. The evolving role of next generation sequencing in myelodysplastic syndromes. Br. J. Haematol. 2020, 188, 224-239. [CrossRef]

24. Besser, J.; Carleton, H.A.; Gerner-Smidt, P.; Lindsey, R.L.; Trees, E. Next-generation sequencing technologies and their application to the study and control of bacterial infections. Clin. Microbiol. Infect. Off. Publ. Eur. Soc. Clin. Microbiol. Infect. Dis. 2018, 24, 335-341. [CrossRef]

25. Pipis, M.; Rossor, A.M.; Laura, M.; Reilly, M.M. Next-generation sequencing in Charcot-Marie-Tooth disease: Opportunities and challenges. Nat. Rev. Neurol. 2019, 15, 644-656. [CrossRef]

26. Mellis, R.; Chandler, N.; Chitty, L.S. Next-generation sequencing and the impact on prenatal diagnosis. Expert Rev. Mol. Diagn. 2018, 18, 689-699. [CrossRef] [PubMed]

27. Cha, Y.J.; Koo, J.S. Next-generation sequencing in thyroid cancer. J. Transl. Med. 2016, 14, 322. [CrossRef]

28. Sabour, L.; Sabour, M.; Ghorbian, S. Clinical Applications of Next-Generation Sequencing in Cancer Diagnosis. Pathol. Oncol. Res. POR 2017, 23, 225-234. [CrossRef]

29. Karnes, H.E.; Duncavage, E.J.; Bernadt, C.T. Targeted next-generation sequencing using fine-needle aspirates from adenocarcinomas of the lung. Cancer Cytopathol. 2014, 122, 104-113. [CrossRef]

30. Zhang, Y.; Li, J.; Hua, P.; Liu, N.; Li, Q.; Zhu, X.; Jiang, L.; Zheng, K.; Su, X. Targeted next-generation sequencing in cytology specimens for molecular profiling of lung adenocarcinoma. Int. J. Clin. Exp. Pathol. 2018, 11, 3647-3655. [PubMed]

31. Chen, Y.; Shi, J.X.; Pan, X.F.; Feng, J.; Zhao, H. Identification of candidate genes for lung cancer somatic mutation test kits. Genet. Mol. Biol. 2013, 36, 455-464. [CrossRef] [PubMed]

32. Wu, K.; Huang, R.S.; House, L.; Cho, W.C. Next-generation sequencing for lung cancer. Future Oncol. 2013, 9, 1323-1336. [CrossRef]

33. Tuononen, K.; Mäki-Nevala, S.; Sarhadi, V.K.; Wirtanen, A.; Rönty, M.; Salmenkivi, K.; Andrews, J.M.; Telaranta-Keerie, A.I.; Hannula, S.; Lagström, S.; et al. Comparison of targeted next-generation sequencing (NGS) and real-time PCR in the detection of EGFR, KRAS, and BRAF mutations on formalin-fixed, paraffin-embedded tumor material of non-small cell lung carcinomasuperiority of NGS. Genes Chromosomes Cancer 2013, 52, 503-511. [CrossRef]

34. Buttitta, F.; Felicioni, L.; Del Grammastro, M.; Filice, G.; Di Lorito, A.; Malatesta, S.; Viola, P.; Centi, I.; D'Antuono, T.; Zappacosta, R.; et al. Effective assessment of egfr mutation status in bronchoalveolar lavage and pleural fluids by next-generation sequencing. Clin. Cancer Res. Off. J. Am. Assoc. Cancer Res. 2013, 19, 691-698. [CrossRef]

35. Lim, S.M.; Kim, E.Y.; Kim, H.R.; Ali, S.M.; Greenbowe, J.R.; Shim, H.S.; Chang, H.; Lim, S.; Paik, S.; Cho, B.C. Genomic profiling of lung adenocarcinoma patients reveals therapeutic targets and confers clinical benefit when standard molecular testing is negative. Oncotarget 2016, 7, 24172-24178. [CrossRef] 
36. Hagemann, I.S.; Devarakonda, S.; Lockwood, C.M.; Spencer, D.H.; Guebert, K.; Bredemeyer, A.J.; Al-Kateb, H.; Nguyen, T.T.; Duncavage, E.J.; Cottrell, C.E.; et al. Clinical next-generation sequencing in patients with non-small cell lung cancer. Cancer 2015, 121, 631-639. [CrossRef]

37. Moskalev, E.A.; Stöhr, R.; Rieker, R.; Hebele, S.; Fuchs, F.; Sirbu, H.; Mastitsky, S.E.; Boltze, C.; König, H.; Agaimy, A.; et al. Increased detection rates of EGFR and KRAS mutations in NSCLC specimens with low tumour cell content by 454 deep sequencing. Virchows Arch. Int. J. Pathol. 2013, 462, 409-419. [CrossRef]

38. Taylor, C.; Chacko, S.; Davey, M.; Lacroix, J.; MacPherson, A.; Finn, N.; Wajnberg, G.; Ghosh, A.; Crapoulet, N.; Lewis, S.M.; et al. Peptide-Affinity Precipitation of Extracellular Vesicles and Cell-Free DNA Improves Sequencing Performance for the Detection of Pathogenic Mutations in Lung Cancer Patient Plasma. Int. J. Mol. Sci. 2020, 21, 9083. [CrossRef] [PubMed]

39. Govind, K.B.; Koppaka, D.; Dasappa, L.; Jacob, L.A.; Babu, S.M.; Lokesh, N.K.; Haleshappa, R.A.; Rajeev, L.K.; Saldanha, S.C.; Abhishek, A.; et al. Detection of clinically relevant epidermal growth factor receptor pathway mutations in circulating cell-free tumor DNA using next generation sequencing in squamous cell carcinoma lung. South Asian J. Cancer 2019, 8, 247-249. [CrossRef]

40. Yamamoto, G.; Kikuchi, M.; Kobayashi, S.; Arai, Y.; Fujiyoshi, K.; Wakatsuki, T.; Kakuta, M.; Yamane, Y.; Iijima, Y.; Mizutani, $\mathrm{H}$; et al. Routine genetic testing of lung cancer specimens derived from surgery, bronchoscopy and fluid aspiration by next generation sequencing. Int. J. Oncol. 2017, 50, 1579-1589. [CrossRef] [PubMed]

41. Li, H.; Xie, Y.; Lin, Y.; Yu, T.; Yin, Z. Different Gene Mutation Spectrum of the Paired CSF and Plasma Samples in Lung Adenocarcinoma with Leptomeningeal Metastases: The Liquid Biopsy Based on Circulating Tumor DNA. Zhongguo Fei Ai Za Zhi = Chin. J. Lung Cancer 2020, 23, 646-654. [CrossRef]

42. Eberhard, D.A.; Johnson, B.E.; Amler, L.C.; Goddard, A.D.; Heldens, S.L.; Herbst, R.S.; Ince, W.L.; Jänne, P.A.; Januario, T.; Johnson, D.H.; et al. Mutations in the epidermal growth factor receptor and in KRAS are predictive and prognostic indicators in patients with non-small-cell lung cancer treated with chemotherapy alone and in combination with erlotinib. J. Clin. Oncol. Off. J. Am. Soc. Clin. Oncol. 2005, 23, 5900-5909. [CrossRef] [PubMed]

43. Lam, T.C.; Tsang, K.C.; Choi, H.C.; Lee, V.H.; Lam, K.O.; Chiang, C.L.; So, T.H.; Chan, W.W.; Nyaw, S.F.; Lim, F.; et al. Combination atezolizumab, bevacizumab, pemetrexed and carboplatin for metastatic EGFR mutated NSCLC after TKI failure. Lung Cancer 2021, 159, 18-26. [CrossRef]

44. Riudavets, M.; Bosch-Barrera, J.; Cabezón-Gutiérrez, L.; Diz Taín, P.; Hernández, A.; Alonso, M.; Blanco, R.; Gálvez, E.; Insa, A.; Mielgo, X.; et al. Efficacy of nintedanib plus docetaxel in patients with refractory advanced epidermal growth factor receptor mutant lung adenocarcinoma. Clin. Transl. Oncol. Off. Publ. Fed. Span. Oncol. Soc. Natl. Cancer Inst. Mex. 2021. [CrossRef]

45. Pratilas, C.A.; Hanrahan, A.J.; Halilovic, E.; Persaud, Y.; Soh, J.; Chitale, D.; Shigematsu, H.; Yamamoto, H.; Sawai, A.; Janakiraman, M.; et al. Genetic predictors of MEK dependence in non-small cell lung cancer. Cancer Res. 2008, 68, 9375-9383. [CrossRef] [PubMed]

46. Facchinetti, F.; Lacroix, L.; Mezquita, L.; Scoazec, J.Y.; Loriot, Y.; Tselikas, L.; Gazzah, A.; Rouleau, E.; Adam, J.; Michiels, S.; et al. Molecular mechanisms of resistance to BRAF and MEK inhibitors in BRAF(V600E) non-small cell lung cancer. Eur. J. Cancer 2020, 132, 211-223. [CrossRef]

47. Sánchez-Torres, J.M.; Viteri, S.; Molina, M.A.; Rosell, R. BRAF mutant non-small cell lung cancer and treatment with BRAF inhibitors. Transl. Lung Cancer Res. 2013, 2, 244-250. [CrossRef]

48. Shibata, T.; Kokubu, A.; Tsuta, K.; Hirohashi, S. Oncogenic mutation of PIK3CA in small cell lung carcinoma: A potential therapeutic target pathway for chemotherapy-resistant lung cancer. Cancer Lett. 2009, 283, 203-211. [CrossRef] [PubMed]

49. André, F.; Ciruelos, E.M.; Juric, D.; Loibl, S.; Campone, M.; Mayer, I.A.; Rubovszky, G.; Yamashita, T.; Kaufman, B.; Lu, Y.S.; et al. Alpelisib plus fulvestrant for PIK3CA-mutated, hormone receptor-positive, human epidermal growth factor receptor-2-negative advanced breast cancer: Final overall survival results from SOLAR-1. Ann. Oncol. Off. J. Eur. Soc. Med Oncol. 2021, 32, $208-217$. [CrossRef] [PubMed]

50. Gao, J.; Wu, H.; Shi, X.; Huo, Z.; Zhang, J.; Liang, Z. Comparison of Next-Generation Sequencing, Quantitative PCR, and Sanger Sequencing for Mutation Profiling of EGFR, KRAS, PIK3CA and BRAF in Clinical Lung Tumors. Clin. Lab. 2016, 62, 689-696. [CrossRef]

51. Xu, X.; Yang, Y.; Li, H.; Chen, Z.; Jiang, G.; Fei, K. Assessment of the clinical application of detecting EGFR, KRAS, PIK3CA and BRAF mutations in patients with non-small cell lung cancer using next-generation sequencing. Scand. J. Clin. Lab. Investig. 2016, 76, 386-392. [CrossRef]

52. Vaughn, C.P.; Costa, J.L.; Feilotter, H.E.; Petraroli, R.; Bagai, V.; Rachiglio, A.M.; Marino, F.Z.; Tops, B.; Kurth, H.M.; Sakai, K.; et al. Simultaneous detection of lung fusions using a multiplex RT-PCR next generation sequencing-based approach: A multi-institutional research study. BMC Cancer 2018, 18, 828. [CrossRef]

53. Benayed, R.; Offin, M.; Mullaney, K.; Sukhadia, P.; Rios, K.; Desmeules, P.; Ptashkin, R.; Won, H.; Chang, J.; Halpenny, D.; et al. High Yield of RNA Sequencing for Targetable Kinase Fusions in Lung Adenocarcinomas with No Mitogenic Driver Alteration Detected by DNA Sequencing and Low Tumor Mutation Burden. Clin. Cancer Res. Off. J. Am. Assoc. Cancer Res. 2019, 25, 4712-4722. [CrossRef] [PubMed]

54. Volckmar, A.L.; Leichsenring, J.; Kirchner, M.; Christopoulos, P.; Neumann, O.; Budczies, J.; Morais de Oliveira, C.M.; Rempel, E.; Buchhalter, I.; Brandt, R.; et al. Combined targeted DNA and RNA sequencing of advanced NSCLC in routine molecular diagnostics: Analysis of the first 3000 Heidelberg cases. Int. J. Cancer 2019, 145, 649-661. [CrossRef] [PubMed] 
55. Frampton, G.M.; Ali, S.M.; Rosenzweig, M.; Chmielecki, J.; Lu, X.; Bauer, T.M.; Akimov, M.; Bufill, J.A.; Lee, C.; Jentz, D.; et al. Activation of MET via diverse exon 14 splicing alterations occurs in multiple tumor types and confers clinical sensitivity to MET inhibitors. Cancer Discov. 2015, 5, 850-859. [CrossRef] [PubMed]

56. Peña-Diaz, J.; Bregenhorn, S.; Ghodgaonkar, M.; Follonier, C.; Artola-Borán, M.; Castor, D.; Lopes, M.; Sartori, A.A.; Jiricny, J. Noncanonical Mismatch Repair as a Source of Genomic Instability in Human Cells. Mol. Cell 2017, 67, 162. [CrossRef]

57. Pfeifer, G.P. Environmental exposures and mutational patterns of cancer genomes. Genome Med. 2010, 2, 54. [CrossRef]

58. Zhao, J.; Xiong, J. Advances on driver oncogenes of non-small cell lung cancer. Zhongguo Fei Ai Za Zhi = Chin. J. Lung Cancer 2015, 18, 42-47. [CrossRef]

59. Liang, W.; Zhao, Y.; Huang, W.; Gao, Y.; Xu, W.; Tao, J.; Yang, M.; Li, L.; Ping, W.; Shen, H.; et al. Non-invasive diagnosis of early-stage lung cancer using high-throughput targeted DNA methylation sequencing of circulating tumor DNA (ctDNA). Theranostics 2019, 9, 2056-2070. [CrossRef] [PubMed]

60. Lin, C.; Shi, X.; Yang, S.; Zhao, J.; He, Q.; Jin, Y.; Yu, X. Comparison of ALK detection by FISH, IHC and NGS to predict benefit from crizotinib in advanced non-small-cell lung cancer. Lung Cancer 2019, 131, 62-68. [CrossRef]

61. Christopoulos, P.; Endris, V.; Bozorgmehr, F.; Elsayed, M.; Kirchner, M.; Ristau, J.; Buchhalter, I.; Penzel, R.; Herth, F.J.; Heussel, C.P.; et al. EML4-ALK fusion variant V3 is a high-risk feature conferring accelerated metastatic spread, early treatment failure and worse overall survival in ALK(+) non-small cell lung cancer. Int. J. Cancer 2018, 142, 2589-2598. [CrossRef]

62. Jin, X.; Chen, Y.; Chen, H.; Fei, S.; Chen, D.; Cai, X.; Liu, L.; Lin, B.; Su, H.; Zhao, L.; et al. Evaluation of Tumor-Derived Exosomal miRNA as Potential Diagnostic Biomarkers for Early-Stage Non-Small Cell Lung Cancer Using Next-Generation Sequencing. Clin. cancer Res. Off. J. Am. Assoc. Cancer Res. 2017, 23, 5311-5319. [CrossRef] [PubMed]

63. Gray, J.; Thompson, J.C.; Carpenter, E.L.; Elkhouly, E.; Aggarwal, C. Plasma Cell-Free DNA Genotyping: From an Emerging Concept to a Standard-of-Care Tool in Metastatic Non-Small Cell Lung Cancer. Oncologist 2021. [CrossRef]

64. Leighl, N.B.; Page, R.D.; Raymond, V.M.; Daniel, D.B.; Divers, S.G.; Reckamp, K.L.; Villalona-Calero, M.A.; Dix, D.; Odegaard, J.I.; Lanman, R.B.; et al. Clinical Utility of Comprehensive Cell-free DNA Analysis to Identify Genomic Biomarkers in Patients with Newly Diagnosed Metastatic Non-small Cell Lung Cancer. Clin. Cancer Res. Off. J. Am. Assoc. Cancer Res. 2019, 25, 4691-4700. [CrossRef]

65. Mack, P.C.; Banks, K.C.; Espenschied, C.R.; Burich, R.A.; Zill, O.A.; Lee, C.E.; Riess, J.W.; Mortimer, S.A.; Talasaz, A.; Lanman, R.B.; et al. Spectrum of driver mutations and clinical impact of circulating tumor DNA analysis in non-small cell lung cancer: Analysis of over 8000 cases. Cancer 2020, 126, 3219-3228. [CrossRef]

66. Cheema, P.K.; Gomes, M.; Banerji, S.; Joubert, P.; Leighl, N.B.; Melosky, B.; Sheffield, B.S.; Stockley, T.; Ionescu, D.N. Consensus Recommendations for Optimizing Biomarker Testing to Identify and Treat Advanced EGFR-Mutated Non-Small-Cell Lung Cancer. Curr. Oncol. 2020, 27, 321-329. [CrossRef] [PubMed]

67. Mosele, F.; Remon, J.; Mateo, J.; Westphalen, C.B.; Barlesi, F.; Lolkema, M.P.; Normanno, N.; Scarpa, A.; Robson, M.; MericBernstam, F.; et al. Recommendations for the use of next-generation sequencing (NGS) for patients with metastatic cancers: A report from the ESMO Precision Medicine Working Group. Ann. Oncol. Off. J. Eur. Soc. Med Oncol. 2020, 31, 1491-1505. [CrossRef]

68. Sueoka-Aragane, N.; Nakashima, C.; Yoshida, H.; Matsumoto, N.; Iwanaga, K.; Ebi, N.; Nishiyama, A.; Yatera, K.; Kuyama, S.; Fukuda, M.; et al. The role of comprehensive analysis with circulating tumor DNA in advanced non-small cell lung cancer patients considered for osimertinib treatment. Cancer Med. 2021, 10, 3873-3885. [CrossRef]

69. Wang, B.; Chen, R.; Wang, C.; Guo, J.; Yuan, M.; Chen, H.; Xia, X.; Zhong, D. Identification of novel ALK fusions using DNA/RNA sequencing in immunohistochemistry/RT-PCR discordant NSCLC patients. Hum. Pathol. 2021, 114, 90-98. [CrossRef] [PubMed]

70. Drilon, A.; Wang, L.; Arcila, M.E.; Balasubramanian, S.; Greenbowe, J.R.; Ross, J.S.; Stephens, P.; Lipson, D.; Miller, V.A.; Kris, M.G.; et al. Broad, Hybrid Capture-Based Next-Generation Sequencing Identifies Actionable Genomic Alterations in Lung Adenocarcinomas Otherwise Negative for Such Alterations by Other Genomic Testing Approaches. Clin. Cancer Res. Off. J. Am. Assoc. Cancer Res. 2015, 21, 3631-3639. [CrossRef] [PubMed]

71. Beadling, C.; Wald, A.I.; Warrick, A.; Neff, T.L.; Zhong, S.; Nikiforov, Y.E.; Corless, C.L.; Nikiforova, M.N. A Multiplexed Amplicon Approach for Detecting Gene Fusions by Next-Generation Sequencing. J. Mol. Diagn. JMD 2016, 18, 165-175. [CrossRef]

72. Dacic, S.; Villaruz, L.C.; Abberbock, S.; Mahaffey, A.; Incharoen, P.; Nikiforova, M.N. ALK FISH patterns and the detection of ALK fusions by next generation sequencing in lung adenocarcinoma. Oncotarget 2016, 7, 82943-82952. [CrossRef]

73. Moskalev, E.A.; Frohnauer, J.; Merkelbach-Bruse, S.; Schildhaus, H.U.; Dimmler, A.; Schubert, T.; Boltze, C.; König, H.; Fuchs, F.; Sirbu, H.; et al. Sensitive and specific detection of EML4-ALK rearrangements in non-small cell lung cancer (NSCLC) specimens by multiplex amplicon RNA massive parallel sequencing. Lung Cancer 2014, 84, 215-221. [CrossRef] [PubMed]

74. Pfarr, N.; Stenzinger, A.; Penzel, R.; Warth, A.; Dienemann, H.; Schirmacher, P.; Weichert, W.; Endris, V. High-throughput diagnostic profiling of clinically actionable gene fusions in lung cancer. Genes Chromosomes Cancer 2016, 55, 30-44. [CrossRef]

75. Clavé, S.; Rodon, N.; Pijuan, L.; Díaz, O.; Lorenzo, M.; Rocha, P.; Taus, Á.; Blanco, R.; Bosch-Barrera, J.; Reguart, N.; et al. Nextgeneration Sequencing for ALK and ROS1 Rearrangement Detection in Patients With Non-small-cell Lung Cancer: Implications of FISH-positive Patterns. Clin. Lung Cancer 2019, 20, e421-e429. [CrossRef]

76. Pekar-Zlotin, M.; Hirsch, F.R.; Soussan-Gutman, L.; Ilouze, M.; Dvir, A.; Boyle, T.; Wynes, M.; Miller, V.A.; Lipson, D.; Palmer, G.A.; et al. Fluorescence in situ hybridization, immunohistochemistry, and next-generation sequencing for detection of EML4-ALK rearrangement in lung cancer. Oncologist 2015, 20, 316-322. [CrossRef] [PubMed] 
77. Jiang, Z.; Li, C.; Lu, H. Next generation sequencing detection in archival surgically resected lung adenocarcinoma specimens harbouring the anaplastic lymphoma kinase fusion protein. JPMA. J. Pak. Med Assoc. 2021, 71, 531-536. [CrossRef]

78. Reckamp, K.L.; Melnikova, V.O.; Karlovich, C.; Sequist, L.V.; Camidge, D.R.; Wakelee, H.; Perol, M.; Oxnard, G.R.; Kosco, K.; Croucher, P.; et al. A Highly Sensitive and Quantitative Test Platform for Detection of NSCLC EGFR Mutations in Urine and Plasma. J. Thorac. Oncol. Off. Publ. Int. Assoc. Study Lung Cancer 2016, 11, 1690-1700. [CrossRef] [PubMed]

79. Liu, C.; Liu, C.; Zou, X.; Shao, L.; Sun, Y.; Guo, Y. Next-generation sequencing facilitates differentiating between multiple primary lung cancer and intrapulmonary metastasis: A case series. Diagn. Pathol. 2021, 16, 21. [CrossRef] [PubMed]

80. Pruneri, G.; De Braud, F.; Sapino, A.; Aglietta, M.; Vecchione, A.; Giusti, R.; Marchiò, C.; Scarpino, S.; Baggi, A.; Bonetti, G.; et al. Next-Generation Sequencing in Clinical Practice: Is It a Cost-Saving Alternative to a Single-Gene Testing Approach? PharmacoEconomics-Open 2021, 5, 285-298. [CrossRef] 